\title{
INTEGRATIVE POTENTIAL OF CENTRAL EUROPEAN METROPOLISES WITH A SPECIAL FOCUS ON THE VISEGRAD COUNTRIES
}

\author{
Martin ŠAUER, Vilém PAŘIL , Milan VITURKA \\ Department of Regional Economics and Administration, Faculty of Economics and Administration, \\ Masaryk University, Lipová 41a, 60200 Brno, Czech Republic
}

Received 22 November 2017; accepted 15 September 2018

\begin{abstract}
One of the characteristic phenomena associated with the current development of civilization is undoubtedly metropolisation. This article focuses on the strategically important problems of the metropolisation of the Central European area with an emphasis on the Visegrad countries. The introductory part is dedicated to the identification of Central European metropolises based on three components: population size, economic profile and investment attractiveness. Designated metropolises are then assessed from the point of view of integrative potential level, including economic interactivity, tourist attractiveness and transport connectivity. Based on the synthesis of these components, the most important axes of supranational importance were identified. It can be said that within the established network of metropolitan axes connecting eastern with western parts of the Central European region the Czech Republic is the best placed, followed by Poland. From a wider geopolitical outlook this network creates favourable conditions for the integration of the Visegrad countries, mainly driven by international trade.
\end{abstract}

Keywords: metropolis, metropolitan axes, interactivity, attractiveness, connectivity.

JEL Classification: O18, R12.

\section{Introduction}

From a long-term perspective, urbanization is probably the most visible manifestation of global socio-economic development. Metropolisation can be understood as a higher stage of urbanization, which is no longer primarily about the concentration of population, but about the concentration of importance. This developmental tendency stimulates horizontal and vertical cooperation of metropolises as an important tool for increasing national and regional competitiveness. Overall, however, it is necessary to say that there is still no clear consensus on the scientific definition of the metropolisation process. The main goal of this paper is a consistent presentation and application of the theoretically anchored method of

\footnotetext{
${ }^{\star}$ Corresponding author. E-mail: vilem@mail.muni.cz

This article was originally published with error. This version has been amended.

Please see Corrigendum https://doi.org/10.3846/tede.2019.10067
}

(C) 2019 The Author(s). Published by VGTU Press

This is an Open Access article distributed under the terms of the Creative Commons Attribution License (http://creativecommons. org/licenses/by/4.0/), which permits unrestricted use, distribution, and reproduction in any medium, provided the original author and source are credited. 
the identification of metropolises and follow-up analyses reflecting the integrative potential of metropolises on the example of the Central European area. For a definition of this area the publications World Factbook (Central Intelligence Agency, 2014), Encyclopædia Britannica (2011), Brockhaus Enzyklopädie (Brockhaus Enzyklopädie Jahrbuch 2009, 2010) and others (e.g. Nováček, 2012) were used. The final region includes nine countries altogether: Germany, Austria, Switzerland plus Liechtenstein, Slovenia and the Visegrad countries, hereinafter V4, i.e. Poland, the Czech Republic, Hungary and Slovakia (in this context it is necessary to draw attention to the relative informative ability of any definition given by the complicated history of the studied area and the political and cultural links to its surroundings.

\section{Methodological and conceptual starting points of the research}

A characteristic feature of the elaborated methodical approach is the generalization of the metropolitan processes, with a specific emphasis on the verified statistical data and the potential synergic effects inducing the dynamic development of metropolitan networks of supranational significance. From a practical point of view, it can be said that the innovative approach used corresponds to the needs of integrated spatial planning whose main objective is permanent strengthening of business, the residential and cultural attractiveness of the regions, all of which creates the basic prerequisites for their sustainable development. According to Potschin, Klug, and Haines-Young (2010) this modern concept connects the planned intentions with the relevant actors in the spirit of a holistic approach.

The utilization of integrated approaches in spatial planning is historically associated with the idea of functionalism, which seeks effective land-use regulation through the controlled allocation of investment. This idea became the mainstream view of the Athens Charter of "modern urbanism" published in 1933. From the present-day documents it is necessary to mention the Charter of European Planning (European Council of Spatial Planners, 2013), whose leitmotiv is the support of integration and cohesion in space and time. A specific example is then the "leitbild" concept, mainly used in German-speaking countries, which was formed in the framework of modern landscape and spatial planning (Klug, 2012). From a broader perspective, this concept can be considered as a search for the "perfect scenario", which extends the possibilities of its use e.g. in the planning of distribution networks and tourist infrastructure (see Bieger, 2008).

As already mentioned, an important part of the elaborated method is the analysis of processes related to the creation of networks of supranational metropolitan axes with significant links to the development of large polycentric settlement systems. These development axes expand the market for goods and services as well as increasing the average distance of commuting for work and therefore have a significant impact on the implementation of national public policies and common policies of the European Union. Their potential impacts on the development of V4 metropolises are evaluated on the basis of three complementary components: general economic interactivity (with important links to economic cooperation and territorial competitiveness), tourist attractiveness (with important links to social relations and territorial cohesion) and transport connectivity (with important links to international trade and territorial quality of life). The final synthesis is then based on the typology of the identified metropolises that can be effectively used in the processing of long-term strategies regarding their development. 


\section{Research database}

The identification of metropolises requires the application of a uniform methodology to ensure international comparability. Accordingly, the OECD has developed a functional "economic areas" method that overcomes distortions associated with administrative division (Organization for Economic Cooperation and Development [OECD], 2012, 2013). This method is based on quantification of travel-to-work flows integrating metropolitan cores with their hinterlands. Given that these data are usually collected only in the censuses, the latest relevant GDP data in PPP are available for 2012 and the population data for 2014 (using the GDP in PPP indicator takes into account different price levels of individual countries as the primary factor of their competitiveness on international markets - see Table 1). The same principle of international comparability also respects the assessment of tourist attractiveness and transport connectivity. Regarding the component of tourism attractiveness, the primary indicator of the evaluation was the number of foreign visitors in collective accommodation facility per year. Most of the data come from the city statistics published by TourMIS. Some missing information (selected Polish and German cities) was added from the regional databases of the national statistical authorities (Statistics Poland, 2017; Statistisches Bundesamt, 2017). In the case of transport connectivity, metropolitan interconnection by air transport was assessed through passenger capacity of flights, based on airport statistics from Eurostat (2017) and data on relevant flights from www.flightradar24.com (Flightradar24, 2017). Time comparison with road traffic connections is based on www.maps.google.com planning module (Google, 2017).

\section{Identification and positioning of metropolises}

The approach used for the identification and positioning of metropolises takes into account the knowledge of a series of regional development theories (Brender \& Golden, 2007; McCann, 2010; Stimson, Stough, \& Roberts, 2006). In this context, we consider as inspiring the theory of localization, of central places, of polarized development and of cumulative causality. Moreover, we also consider the utilization of the theory of integrated and sustainable regional development to be beneficial. This theory (Viturka, 2014) stresses that the characteristic feature of human progress is the hierarchical differentiation of societal systems and their integration through the territorial division of labour. The resulting spatial arrangement ensures the coherence of systems reflecting the achieved degree of balance between the economic, social and ecological factors. Regarding the spatial integration of systems, the following driving forces are then considered to be decisive: labour interactions on a microregional level, production interactions on a mesoregional level, administrative interactions on a macroregional level and trade interactions on a global level. The ambiguity of the metropolisation concept complicates the assessment of the metropolises, starting with the definition itself. The elaborated and practically verified method of identifying them was therefore based on three both quantitative and qualitative components:

1. population of the metropolises, a sufficient size of which is generally regarded as the initial assumption for starting the metropolisation process;

2. economic profile emphasizing the share of knowledge-based industries; 
3. investment attractiveness as a reflection of the quality of the business and social environments.

In the case of population size, it should be mentioned that there is a lack of clear distinction between metropolises and other major cities (it is necessary to take into account the comparability of their territorial delimitation). In this context, one million inhabitants are considered as the basic size limit of supranational significant metropolitan regions. In the case of metropolitan regions of secondary importance, the commonly used limit is half a million inhabitants (Brezzi, Piacentini, Rosina, \& Sanchez-Serra, 2012). In our case, a total of 27 metropolises or metropolitan regions were identified.

The progressive economic profile is regarded as a typical feature of metropolises. The logic of this classification is not significantly disputed (Globalization and World Cities [GaWC], 2014; Žítek, Klímová, \& Králová, 2016). In this context, the metropolises were distributed into the following groups (Krätke, 2006, 2014):

1. Group A: above average proportion of HTI (research-intensive high technology industrial branches) + MTI (research-intensive medium high technology industrial branches) + TS (knowledge-intensive technology-related services).

2. Group B: above average proportion of ES (knowledge-intensive market-related enterprise services) + FS (knowledge-intensive financial services) + HEM (knowledgeintensive services in healthcare, education and the media industry).

3. Group C: average proportion of knowledge-based industries with a better position of technology-related branches (HTI + MTI + TS).

4. Group D: average proportion of knowledge-based industries with a better position of service-related branches (ES + FS + HEM).

5. Group E: below average proportion of research and knowledge-intensive branches.

In order to assess the economic profile, the Eurostat Regio database was selected. The final evaluation works with three classification groups, when metropolises of groups A and $\mathrm{B}$ are included in the above-average category, metropolises of groups $\mathrm{C}$ and $\mathrm{D}$ in the average category, and metropolises of group $\mathrm{E}$ in the below-average category. Based on the given groups, regional employment was compared to total employment and the shares found were used for the classification of national metropolises. The highest number of metropolises fall in the above-average and average categories (the best category includes Stuttgart, Mannheim, Hannover, Nuremberg, Hamburg, Munich, Frankfurt a. M. and all Swiss metropolises; the below average category includes only the Polish metropolises with the exception of Warsaw and Katowice).

The quality of the business environment (QBE) occupies a central position in the case of the evaluation of the investment attractiveness of metropolises and its inclusion balances a certain partiality of both previous components. Verified information from the European Cities Monitor (Cushman \& Wakefield, 2011), was used for its evaluation. Due to the lack of geographic coverage of the whole examined region, this information was completed by data obtained from the benchmarking of large cities created by the HWWI/Berenberg bank, the results of the aggregate rating of localization advantages (Neumann, 2013) and the database of GaWC, Loughborough University. The assessed metropolises can be divided from a broader perspective into three categories: 
Table 1. Data about the population (2014) and GDP (2012) of Central European states and metropolises (source: OECD, 2018; own calculations)

\begin{tabular}{|c|c|c|c|c|c|c|}
\hline $\begin{array}{l}\text { Country/ } \\
\text { metropolitan } \\
\text { region }\end{array}$ & Population & $\begin{array}{l}\text { Pop. density } \\
\text { (per inh./ } \\
\mathrm{km}^{2} \text { ) }\end{array}$ & $\begin{array}{l}\text { Pop. Growth - } \\
\text { metro/state } \\
(2008-2014)\end{array}$ & $\begin{array}{l}\text { GDP-mil. } \\
\text { USD/PPP }\end{array}$ & $\begin{array}{l}\text { GDP-USD } \\
\text { per capita }\end{array}$ & $\begin{array}{c}\text { Growth } \\
\text { of GDP } \\
\text { metro/state } \\
(2008-2012)\end{array}$ \\
\hline Poland & 38017856 & 122 & $x$ & 841841 & 21844 & $x$ \\
\hline Warsaw & 3037890 & 353 & 1.03 & 138448 & 46013 & 1.05 \\
\hline Katowice $^{*}$ & 2589349 & 660 & 0.98 & 64791 & 24837 & 0.96 \\
\hline Krakow & 1362740 & 363 & 1.02 & 35283 & 25997 & 0.99 \\
\hline Gdansk & 1105467 & 423 & 1.02 & 30061 & 27367 & 1.09 \\
\hline Lodz & 939568 & 555 & 0.98 & 23110 & 24384 & 0.97 \\
\hline Poznan & 950596 & 309 & 1.03 & 33815 & 35900 & 1.00 \\
\hline Wroclaw & 837995 & 318 & 1.01 & 25968 & 31084 & 1.05 \\
\hline Czech Rep. & 10512419 & 136 & $x$ & 286885 & 27350 & $x$ \\
\hline Prague & 1910396 & 486 & 1.05 & 86434 & 46255 & 0.98 \\
\hline Hungary & 9879365 & 106 & $x$ & 215424 & 21690 & $x$ \\
\hline Budapest & 2879601 & 475 & 1.03 & 102940 & 35964 & 1.01 \\
\hline Slovakia & 5415949 & 110 & $x$ & 137455 & 25434 & $x$ \\
\hline Bratislava & 729157 & 280 & 1.03 & 40168 & 55626 & 1.03 \\
\hline Germany & 80767463 & 226 & $x$ & 3363274 & 41094 & $x$ \\
\hline Berlin & 4399542 & 712 & 1.03 & 165377 & 37701 & 1.03 \\
\hline Rhine-Ruhr ${ }^{*}$ & 7066185 & 969 & 1.01 & 315059 & 44439 & 0.99 \\
\hline Hamburg & 3008841 & 522 & 1.03 & 158074 & 52748 & 0.96 \\
\hline Munich & 2965871 & 474 & 1.08 & 184701 & 63592 & 1.04 \\
\hline Frankfurt/ M. & 2533311 & 652 & 1.03 & 143516 & 56828 & 0.94 \\
\hline Stuttgart & 1965942 & 989 & 1.03 & 108877 & 55541 & 1.01 \\
\hline Mannheim & 1230276 & 631 & 1.00 & 55014 & 44525 & 0.98 \\
\hline Hannover & 1217511 & 394 & 1.01 & 55136 & 45190 & 1.01 \\
\hline Nuremberg & 1169367 & 374 & 1.02 & 56100 & 48025 & 1.03 \\
\hline Bremen & 1027192 & 323 & 1.02 & 44594 & 43448 & 0.97 \\
\hline Leipzig & 830318 & 391 & 1.00 & 27933 & 33500 & 1.05 \\
\hline Dresden & 847600 & 494 & 1.04 & 26969 & 32024 & 0.98 \\
\hline Austria & 8506889 & 103 & $x$ & 363549 & 43238 & $x$ \\
\hline Vienna & 2793631 & 307 & 1.04 & 129516 & 47307 & 0.99 \\
\hline Switzerland & 8139631 & 204 & $x$ & 413368 & 51966 & $x$ \\
\hline Zürich & 1246968 & 1060 & 0.98 & 77011 & 62798 & 0.99 \\
\hline Geneva & 831452 & 531 & 1.02 & 43897 & 54352 & 1.00 \\
\hline Basel & 780223 & 546 & 0.96 & 41375 & 53502 & 0.99 \\
\hline Slovenia & 2061085 & 102 & $x$ & 55313 & 26910 & $x$ \\
\hline Ljubljana & 585850 & 186 & 1.02 & 21567 & 37419 & 1.09 \\
\hline
\end{tabular}

Notes: *The figure is related to the polycentric metropolitan region Rhine-Ruhr (consists of Düsseldorf, Cologne, Dortmund, Duisburg, Essen, Bonn and Bochum) and Upper Silesia (Katowice, Sosnowiec and other cities). 
1. Metropolises of global importance - five metropolises (Frankfurt a. M., Berlin, Munich, Zürich, Rhine-Ruhr).

2. Metropolises of European importance - seven metropolises (Geneva, Hamburg, Prague, Vienna, Warsaw, Stuttgart, Budapest).

3. Metropolises of Central European importance - remaining fifteen metropolises.

For a comprehensive evaluation of metropolises, a typological method was chosen to classify phenomena according to the similarity of the selected characteristics due to data comparability problems. In our case, we dealt with the functional positioning of metropolises according to components of population size, economic profile and investment attractiveness. The metropolises were classified into dominant, established and elementary types (see Figure 1). The statistical analysis shows that the type classification of the metropolises has the strongest link to the component investment attractiveness, with a correlation coefficient $k=$ 0.85 . The results logically showed a significantly better position of western metropolises with a threefold weaker representation of the elementary type in comparison with the eastern metropolises.

\section{Interactive analysis of Visegrad metropolises}

As already indicated, the metropolises represent one of the main symbols of changes in the scale and form of urbanization happening in the background of the globalization process (Hanssens, Derudder, \& Witlox, 2012). This development supports the strengthening of the metropolitan axes, which thus become an ever more dominant part of urban systems (Parr, 2014). Spread effects stimulating a gradual transition from traditional monocentric systems to cooperating polycentric systems are symptomatic for fully developed axes (Growe, 2012). The corresponding objective of relevant analyses is then to assess their supranational integration potential. This analysis involves three components: general economic interactivity, tourist attractiveness and transport connectivity. In this context, we will focus on the evaluation of interactions between V4 metropolises and the western part of the Central European area.

\subsection{General economic interactivity}

The evaluation of economic interactivity (Matsumoto, Domae, \& O'Connor, 2016; Calatayud, Palacin, Mangan, Jackson, \& Ruiz-Rua, 2016) is based on a modified gravity model as a standard tool of a qualified estimate of potential interactions, especially in conditions of insufficient data availability:

$$
G_{i j}=\frac{m_{i} \times m_{j}}{d_{i j}},
$$

where $G_{i j}$ - the economic force acting between the metropolises, $m_{i j}$ - the economic importance of metropolises and $d_{i j}$ - the distance of concerned metropolises. For measuring the importance, GDP data available for metropolitan regions in 2012 were used, and the distance of the metropolises reflects the length of the fastest motorway/road connection (taking into account the permitted daily driving time of trucks under the EU regulation, which cor- 
responds to a maximum distance of 600 to $700 \mathrm{~km}$ ). The supranational metropolitan axes defined on the basis of aggregated $G_{\text {sum }}$ values then occupy the most important position in terms of integration potential. The used model shows the strongest supranational links of Warsaw with Berlin, of Prague with Berlin and Munich, of Budapest with Vienna and of Bratislava with Vienna. From a theoretical perspective, the development importance of metropolises documents the creation and diffusion of urban or localization savings in the spirit of agglomeration economies.

The economic importance of defined supranational axes confirm the decisive shares of the German "Ländern" in the foreign trade of the Czech Republic after 1989- export/import: Bavaria 29/16\%, Baden-Württemberg 19/14\%, Nord Rhine-Westphalia 14/14\%, Lower Saxony $8 / 8 \%$, Saxony $10 / 5 \%$ and Hesse $6 / 4 \%$; to a large extent we come across a similar order in the case of Poland, where the north eastern German regions are logically somewhat more involved (see Statistisches Bundesamt, 2016; Wydział Ekonomiczno-Handlowy - Ambasada $\mathrm{RP} w$ Berlinie, 2005). In this context it is important to remember that Germany is the most important economic partner not only for all V4 countries (the strongest position in this respect is held by the Czech Republic with the best geographic position, followed by Hungary), but also for all the remaining countries of the examined Central European area. A similar spatial pattern can be assumed even in the case of foreign direct investment. In this context, however, it is necessary to note that regional statistics related to international trade and direct investment in all the countries concerned are highly fragmented or not available, with the exception of Germany.

The defined metropolitan axes of supranational importance have been divided into three statistical groups - axes of 1st, 2nd and 3rd order based on the generalized border values $G_{\text {sum }} 40$ and $G_{\text {sum }} 20$ established in accordance with their integration significance, when the first group comprises 8 out of a total of 18 axes (see Table 2$)^{1}$. In this context, it is an important finding that all major V 4 metropolises (especially Warsaw and Prague) are linked to the closest German metropolises and further with Vienna by the historically constituted axes of the highest category. This fact can be seen as confirmation of their intensive involvement in international economic cooperation.

Metropolitan axes of supranational importance naturally interconnect the most important spatial concentrations of economic and social activities. Their two-way interactions create developmental impulses that ensure the external equilibrium of societal systems. The acquired knowledge can be considered an important prerequisite for useful optimization of the territorial division of labour through public support for competitive and sustainable development, restricting the production of negative externalities (in particular, urban congestion of the metropolitan regions degrading the quality of life). This support should respect the spatial impact of diverse economic and non-economic measures and prioritise integrated approaches over isolated efforts to stimulate long-term development through partial policy motivated measures (in this context, it is appropriate to mention a certain analogy with the system approach to maintenance and support of the development of bio-centres and bio-corridors as essential components of territorial systems of landscape ecological stability).

\footnotetext{
${ }^{1}$ Ljubljana was not included in the analyses due to marginal importance for economic integration of V4 countries.
} 


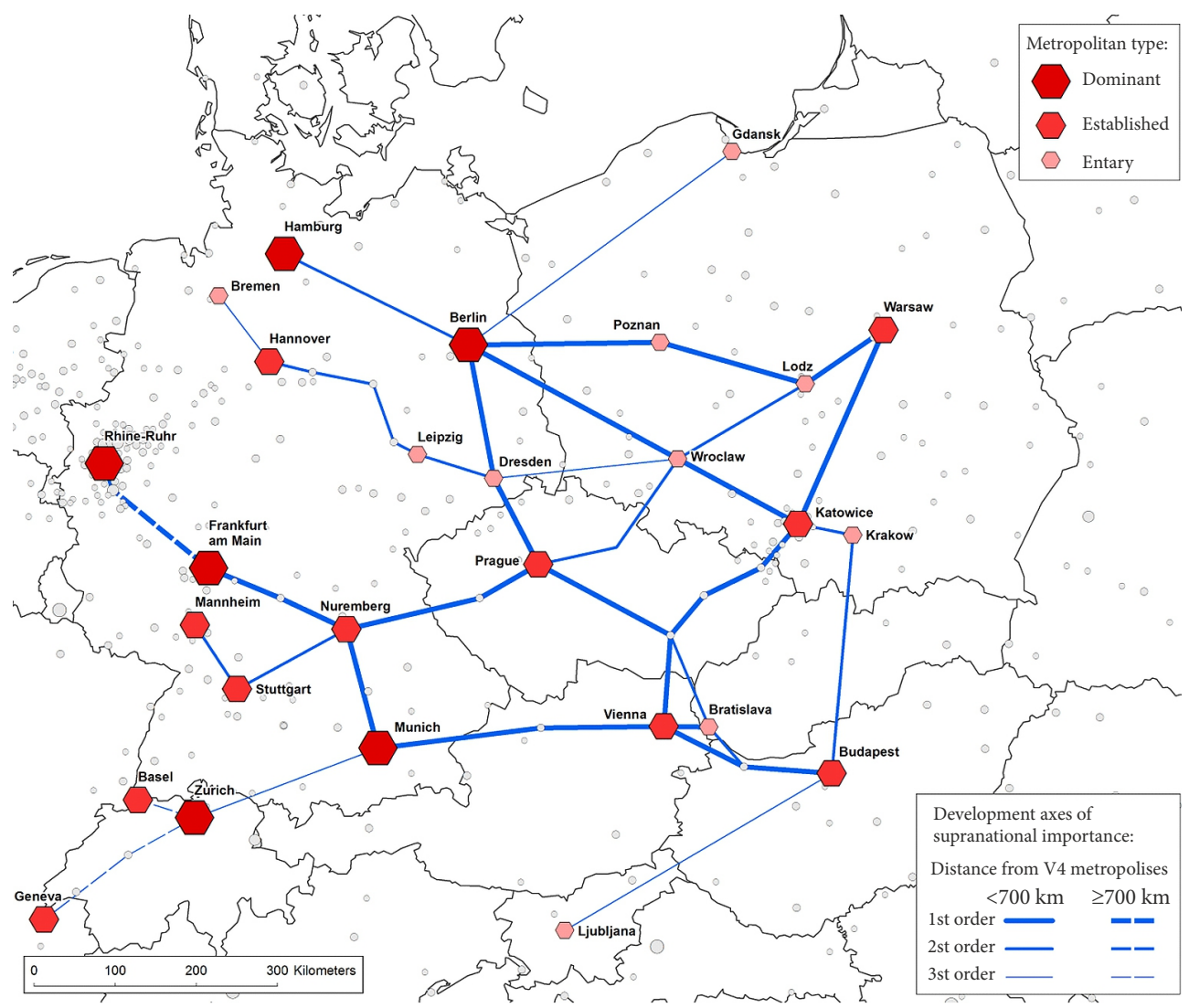

Figure 1. The metropolitan system of the Central European area from the point of view of the V4 countries (source: Viturka, Pařil, Tonev, Šašinka, \& Kunc, 2017)

Table 2. Metropolitan axes of supranational importance (source: OECD, 2012, 2018; own calculations)

\begin{tabular}{|l|c|c|}
\hline \multicolumn{1}{|c|}{ Metropolitan axis } & $G_{\text {sum }}$ & Group \\
\hline Prague - Nuremberg - Munich - Zürich & $58 / 68$ & 1 \\
\hline Prague - Dresden - Berlin - Hamburg & $57 / 79$ & 1 \\
\hline Prague - (Nuremberg) - Frankfurt a. M. - Rhine-Ruhr & $36 / 73$ & 1 \\
\hline Prague - (Nuremberg) - Stuttgart - Mannheim & 29 & 2 \\
\hline Prague - (Dresden) - Leipzig - Hannover - Bremen & $20 / 26$ & 2 \\
\hline Prague - Vienna & 35 & 2 \\
\hline Prague - Bratislava - Budapest & 28 & 2 \\
\hline Prague - Wroclaw - Lodz - Warsaw & $11 / 29$ & 2 \\
\hline Prague - Katowice & 12 & 3 \\
\hline Warsaw - Lodz - Poznan - Berlin & 69 & 1 \\
\hline Krakow - Katowice - Wroclaw - Berlin & 43 & 1 \\
\hline Warsaw - Katowice - Vienna & $22 / 49$ & 1 \\
\hline
\end{tabular}


End of Table 2

\begin{tabular}{|l|c|c|}
\hline \multicolumn{1}{|c|}{ Metropolitan axis } & $G_{\text {sum }}$ & Group \\
\hline Katowice - (Wroclaw) - Dresden - Leipzig & 12 & 3 \\
\hline Gdansk - Berlin & 10 & 3 \\
\hline Warsaw - Katowice - Bratislava & $7 / 15$ & 3 \\
\hline Budapest - Vienna - Munich & $55 / 84$ & 1 \\
\hline Budapest - Krakow - Katowice & 24 & 2 \\
\hline Bratislava - Vienna & 66 & 1 \\
\hline
\end{tabular}

Notes: $G_{\text {sum }}$ - metropolises in distance to $600 \mathrm{~km} ; G_{\text {sum }}$ - metropolises in an extended distance up to $700 \mathrm{~km}$ (Nuremberg etc.) - relevant value $\mathrm{G}$ is assigned to another axis.

\subsection{Tourist attractiveness}

The intensity of the tourist flows is determined from the spatial point of view by the attractiveness of the destination, the population size of the source centres and the distance between them. Modelling of tourist flows is based on information on the demand for metropolises under investigation and identification of sources of this demand using the gravity model. From the TourMIS database (Wöber, 2003), which aggregates the data of the National Statistical Offices, we gained an overview of the geographical structure of the metropolitan traffic for 2015. The next step was to estimate the volume of traffic that falls on the source metropolis. Here we based our information on the share of the population of the origin metropolis in the total population of the state. Using the gravity model for the distribution of relevant national flows into the metropolises between the cities of origin and the estimating differences in the purchasing power of the metropolitan population, the tourist flows between each of the two investigated metropolises were determined. This analysis focuses on assessing the links between the V4 metropolises and the remaining 16 Central European metropolises except Ljubljana. According to the statistical offices of the respective countries, 40.5 million foreign tourists were accommodated in all cities in 2015 (more than half have less than 1 million foreign tourists). Just two metropolises, Prague (5.7 million) and Vienna (5.5 million), generate $28 \%$ of all traffic. In the V4 country, this is about $1 / 3$ of the performance.

Based on the application of the gravity model, a total of 184 tourist international flows were identified from the perspective of the V4 countries. Each interaction includes a two-way flow of visitors. The total volume of interactions reaches 1.26 million visitors, which means less than $10 \%$ of all Central European metropolitan traffic. Above-average links to these metropolises were found in Wroclaw (16\%), Poznan (14\%) and Bratislava (11\%). On the other hand, Budapest and Krakow (Prague is slightly below average) showed the weakest links. The geographical distribution of the most significant tourist flows is illustrated in the Table 3 and Figure 2. It can be said that the differences in the strength of the tourist flows are very significant when roughly half of their volume is generated by the first 19 interactions. Prague's share of these flows is about $40 \%$. About half of the value is achieved by Budapest, which is significantly behind Prague in inbound tourism (on the other hand it has the strongest position in outbound tourism within the V4 countries). Bratislava and Warsaw are significantly 
behind with a share of only $11 \%$ and $7 \%$ respectively. The attractive Krakow then occupies the fifth position. A strong historical link with Prague is seen in the relatively stable position of Bratislava as the smallest metropolis of V4.

The V4 countries show a positive balance of tourist flows with the Central European metropolises. In total, more than 0.5 million visitors arrive than leave each country. This balance is at the expense of "Western" metropolises (the only metropolis with a positive balance is Vienna). Concerning individual tourist flows, nine of the ten most important ones are related to visits to Prague with the only exception of the flow Budapest - Vienna, which comes second after the Prague - Vienna flow. Besides Vienna, Prague still has strong tourism links to Bratislava, Berlin, Rhine-Ruhr, Munich and Budapest. Somewhat weaker are links to Frankfurt am M., Dresden and Hamburg. Prague's spatial ties are oriented mainly to the West-East direction, dominated by significant German metropolises along with Vienna (the connection of Prague to Poland appears to be of little importance). Budapest also exhibits a similar model of spatial ties with dominant links to Vienna, Prague, Berlin and RhineRuhr. In the case of Bratislava, traditional ties to Prague and Vienna prevail. Warsaw shows significantly weaker links to the metropolis of the V4 countries and the German metropolis, which are the most important for it.

Table 3. Inbound and outbound tourism in the metropolises V4 (source: TourMIS database, 2017; own calculations)

\begin{tabular}{|l|c|c|c|l|l|}
\hline Metropolises & Inbound & Outbound & Total & $\begin{array}{l}\text { Main source for } \\
\text { inbound tourism flow }\end{array}$ & $\begin{array}{l}\text { Main destination for } \\
\text { outbound tourism flow }\end{array}$ \\
\hline Prague & 496603 & 108593 & 605196 & $\begin{array}{l}\text { Berlin, Vienna, } \\
\text { Bratislava, Rhine-Ruhr }\end{array}$ & $\begin{array}{l}\text { Bratislava, Vienna, } \\
\text { Budapest }\end{array}$ \\
\hline Budapest & 185654 & 126950 & 312604 & $\begin{array}{l}\text { Vienna, Berlin, } \\
\text { Rhine-Ruhr }\end{array}$ & Vienna, Prague \\
\hline Bratislava & 86153 & 75948 & 162101 & Prague, Vienna & $\begin{array}{l}\text { Prague, Budapest, } \\
\text { Vienna }\end{array}$ \\
\hline Warsaw & 57230 & 48294 & 105524 & Berlin, Rhine-Ruhr & Prague, Berlin \\
\hline Krakow & 66663 & 22181 & 88844 & $\begin{array}{l}\text { Budapest, Berlin, } \\
\text { Vienna }\end{array}$ & $\begin{array}{l}\text { Prague, Budapest, } \\
\text { Berlin, Vienna }\end{array}$ \\
\hline Wroclaw & 48834 & 17873 & 66707 & Berlin, Rhine-Ruhr & Prague, Berlin \\
\hline Katowice & 11391 & 44679 & 56070 & Berlin, Rhine-Ruhr & $\begin{array}{l}\text { Prague, Vienna, Berlin, } \\
\text { Budapest }\end{array}$ \\
\hline Poznan & 28087 & 20106 & 48193 & $\begin{array}{l}\text { Berlin, Rhine-Ruhr, } \\
\text { Hamburg }\end{array}$ & Berlin, Prague \\
\hline Gdansk & 29479 & 13068 & 42547 & $\begin{array}{l}\text { Berlin, Rhine-Ruhr, } \\
\text { Hamburg }\end{array}$ & Berlin, Prague \\
\hline Lodz & 9376 & 13774 & 23150 & Berlin, Rhine-Ruhr & Prague, Berlin \\
\hline Total & 1019470 & 491466 & 1510937 & & \\
\hline
\end{tabular}

Notes: The total sum of the tourist flows includes duplicate information (for example, the departure from the metropolis is also the arrival to another metropolis). 
The examined metropolitan links were divided into four groups based on the intensity of the relationships, reflecting the strength of the individual tourist flows (see Figure 2). The most important links were included in the first and second groups, which include 8 out of a total of 42 tourist interactions of transnational significance. The third group consisted of 9 interactions and the remaining 25 interactions belong to the last group. With the exception of the two interactions (the Prague - Bratislava and Prague - Budapest links), the strongest tourist interactions logically refer to the richer and more populous "Western" metropolises. Therefore, we find the more frequent occurrence of interactions between V4 metropolises in the third and fourth groups. This clearly shows the economic power of Germany (or Austria and Switzerland), which is the primary source market for almost all V4 metropolitan areas.

By the analyses carried out, the metropolitan tourist axes were identified at the final stage (see Table 4). Similarly, to the general economic interactivity and transport connectivity components, the metropolitan axes were divided into three groups according to the intensity of accumulated tourist flows (TFsum). Compared to economic interactivity, tourist attractiveness is more diversified. The reason is primarily the nature of tourism, which benefits from the uniqueness and specificity of destination. The most significant group contains only 5 out of a total of 18 defined axes. Except for the Prague - Bratislava - Budapest axis, all the most important axes are oriented to the German metropolis, complemented by Vienna.

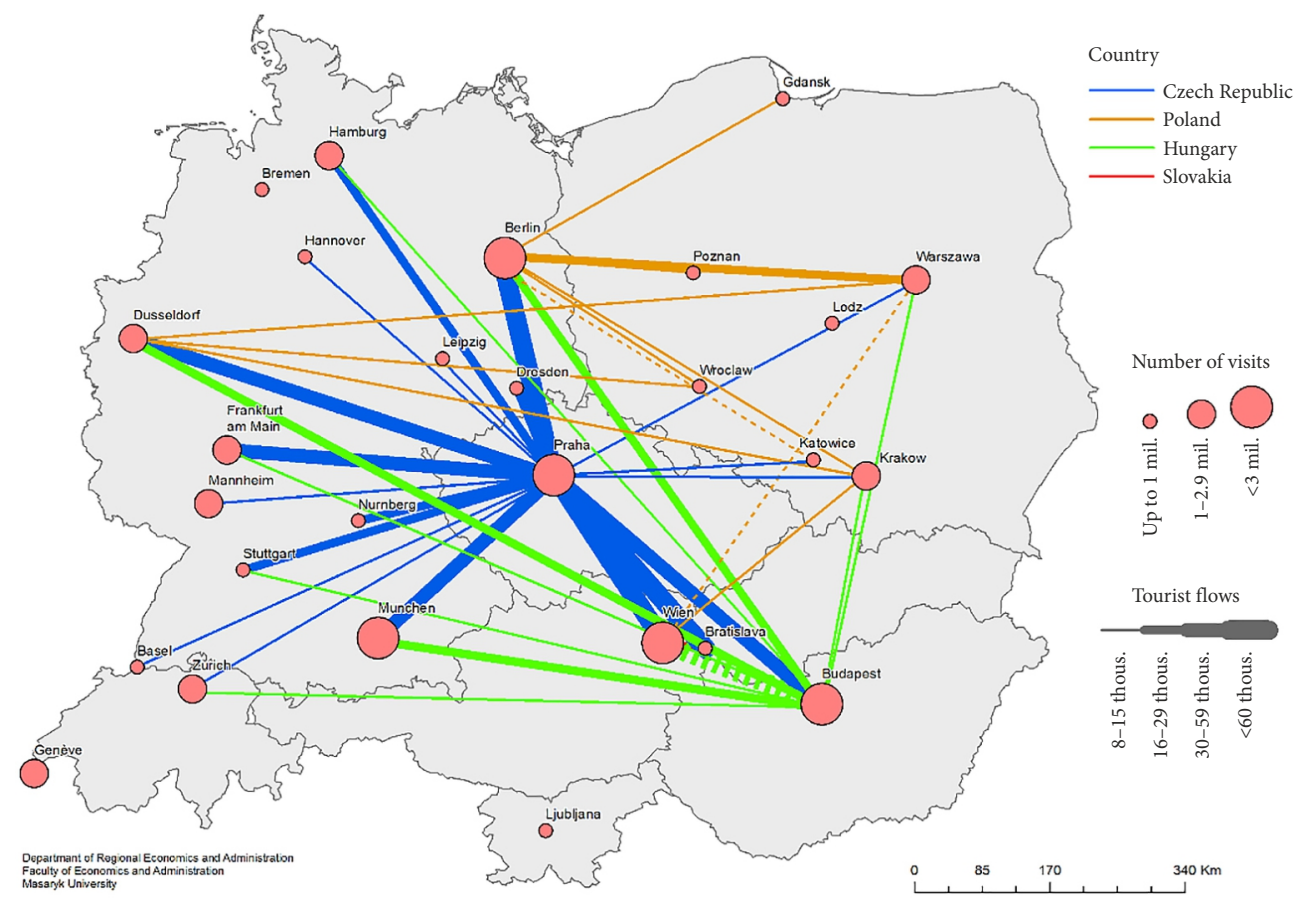

Figure 2. The tourist flows of the Central European area from the point of view of the V4 countries (source: TourMIS database, 2017)

Notes: Continuous lines represents tourist flows with arrivals > departures to V4 metropolises, dashed lines represents airlines with departures $>$ arrivals. 
Table 4. Tourist metropolitan axes (source: own calculations)

\begin{tabular}{|l|c|c|}
\hline \multicolumn{1}{|c|}{ Metropolitan axes } & $T F_{\text {sum } /} T F_{\text {sum }}$ & Group \\
\hline Prague - Nuremberg - Munich - Zürich & $79 / 94$ & 1 \\
\hline Prague - Dresden - Berlin - Hamburg & $128 / 165$ & 1 \\
\hline Prague - (Nuremberg) - Frankfurt a. M. - Rhine-Ruhr & $39 / 87$ & 1 \\
\hline Prague - (Nuremberg) - Stuttgart - Mannheim & 52 & 2 \\
\hline Prague - (Dresden) - Leipzig - Hannover - Bremen & $48 / 63$ & 2 \\
\hline Prague - Vienna & 67 & 2 \\
\hline Prague - Bratislava - Budapest & 109 & 1 \\
\hline Prague - Wroclaw - Lodz - Warsaw & $10 / 24$ & 3 \\
\hline Prague - Katowice & 11 & 3 \\
\hline Warsaw - Lodz - Poznan - Berlin - $\underline{\text { Hannover - Rhine-Ruhr }}$ & $38 / 57$ & 2 \\
\hline Krakow - Katowice - Wroclaw - Berlin - Hamburg & $34 / 46$ & 2 \\
\hline Warsaw - Katowice - Vienna & $8 / 17$ & 3 \\
\hline Krakow - Katowice - (Wroclaw) - Dresden - Leipzig - Rhine-Ruhr & $10 / 32$ & 2 \\
\hline Warsaw - (Katowice) - Budapest & 19 & 3 \\
\hline Budapest - Vienna - Munich - urich & $71 / 98$ & 1 \\
\hline Budapest - Krakow - Katowice & 12 & 3 \\
\hline Bratislava - Vienna & 31 & 2 \\
\hline Budapest - Nuremberg - Frankfurt a. M. - Rhine-Ruhr (new axis) & 40 & 2 \\
\hline
\end{tabular}

Notes: $T F_{\text {sum }}$ - metropolises in distance to $600 \mathrm{~km} ; T F_{\text {sum }}$ - metropolises in distance $600 \mathrm{~km}$; (Nuremberg) relevant value of TF is assigned to another axis; metropolises not included in the axis in Table 2 are underlined.

There is a different situation in the Polish cities, which show weaker tourist links both to Germany and other V4 metropolis. Budapest, on the other hand, boosted its tourist attractiveness and, besides the traditional axis of Budapest - Vienna - Munich, a new tourist axis is being set up for Nuremberg, Frankfurt and M. and Rhine-Ruhr. Overall, however, the tourism processes in the Central European area result in a very similar picture of the distribution of economic and social activities in the territory. It can be said that the tourist attraction of the V4 metropolises through the development of tourism strengthens its links with its natural economic partners, and the less attractive metropolises for tourists in this direction tend to follow these links, with the importance of tourism for their economic development usually being marginal.

\subsection{Transport connectivity}

Transport connectivity is generally understood as the degree of interconnection of urban nodes by different types of transport network. In this case it is aviation (Arvis \& Shepherd, 2016) and road (Liu, Dai, \& Derudder, 2017) transport. In this regard, the location of a large international airport (Duval, 2013; Suau-Sanchez, Voltes-Dorta, \& Rodriguez-Deniz, 2016) is considered to be a significant metropolitan symbol. The influence of dynamic spatial and temporal organization of air transport in Central Europe has been researched in Kraft (2016). 
Table 5. Role of metropolises in the air transport sector in the Central European area (source: Eurostat, 2017; Flightradar24, 2017; own calculations)

\begin{tabular}{|c|c|c|c|c|c|c|c|c|}
\hline \multirow[b]{2}{*}{ Metropolises } & \multicolumn{4}{|c|}{ Central European flights } & \multicolumn{4}{|c|}{ All flights } \\
\hline & Flights & $\begin{array}{c}\text { Passengers } \\
\text { (estimate) }\end{array}$ & $\begin{array}{c}\text { Flights } \\
(\%)\end{array}$ & $\begin{array}{c}\text { Capacity } \\
(\%)\end{array}$ & Flights & Passengers & $\begin{array}{c}\text { Flights } \\
(\%)^{*}\end{array}$ & $\begin{array}{c}\text { Capacity } \\
(\%)^{*}\end{array}$ \\
\hline Munich & 211016 & 25549954 & 14.0 & 14.8 & 361288 & 40860798 & 58 & 63 \\
\hline Frankfurt/M & 174653 & 22709296 & 11.6 & 13.1 & 482899 & 63486473 & 36 & 36 \\
\hline Rhine-Ruhr & 135050 & 15894108 & 8.9 & 9.2 & 358939 & 34736449 & 38 & 46 \\
\hline Düsseldorf & 124191 & 14268033 & 8.2 & 8.2 & 202764 & 22448170 & 61 & 64 \\
\hline Cologne & 3422 & 547500 & 0.2 & 0.3 & 128537 & 10313744 & 3 & 5 \\
\hline Dortmund & 7437 & 1078575 & 0.5 & 0.6 & 27638 & 1974535 & 27 & 55 \\
\hline Hamburg & 111279 & 14417318 & 7.4 & 8.3 & 158197 & 15583550 & 70 & 93 \\
\hline Berlin & 97364 & 13343716 & 6.4 & 7.7 & 260274 & 29507852 & 37 & 45 \\
\hline Vienna & 99919 & 13005269 & 6.6 & 7.5 & 219762 & 22739777 & 45 & 57 \\
\hline Zurich & 112968 & 12808215 & 7.5 & 7.4 & 231095 & 26251507 & 49 & 49 \\
\hline Warsaw & 101379 & 8216926 & 6.7 & 4.7 & 155045 & 13807622 & 65 & 60 \\
\hline Stuttgart & 69122 & 7694884 & 4.6 & 4.4 & 136057 & 10488111 & 51 & 73 \\
\hline Geneva & 52013 & 5890142 & 3.4 & 3.4 & 146440 & 15682128 & 36 & 38 \\
\hline Budapest & 42021 & 4531749 & 2.8 & 2.6 & 92294 & 10228352 & 46 & 44 \\
\hline Prague & 44804 & 4004278 & 3.0 & 2.3 & 117903 & 11867665 & 38 & 34 \\
\hline Hannover & 28698 & 3416126 & 1.9 & 2.0 & 94563 & 5433235 & 30 & 63 \\
\hline Nuremberg & 35542 & 3149631 & 2.4 & 1.8 & 59304 & 3351902 & 60 & 94 \\
\hline Basel & 28744 & 2972332 & 1.9 & 1.7 & 59110 & 6315329 & 49 & 47 \\
\hline Dresden & 25459 & 2554361 & 1.7 & 1.5 & 29310 & 2804190 & 87 & 91 \\
\hline Kraków & 27968 & 2468860 & 1.9 & 1.4 & 36302 & 4213036 & 77 & 59 \\
\hline Bremen & 18022 & 2230698 & 1.2 & 1.3 & 40623 & 2657613 & 44 & 84 \\
\hline Leipzig & 20942 & 2188266 & 1.4 & 1.3 & 64457 & 2304110 & 32 & 95 \\
\hline Gdansk & 23999 & 2078128 & 1.6 & 1.2 & 40261 & 3696829 & 60 & 56 \\
\hline Wroclaw & 19893 & 1714268 & 1.3 & 1.0 & 24510 & 2263358 & 81 & 76 \\
\hline Katowice & 9901 & 1093859 & 0.7 & 0.6 & 27397 & 3047915 & 36 & 36 \\
\hline Poznan & 11041 & 717773 & 0.7 & 0.4 & 21819 & 1483810 & 51 & 48 \\
\hline Bratislava & 2464 & 231319 & 0.2 & 0.1 & 23670 & 1555558 & 10 & 15 \\
\hline Lódz & 2190 & 137970 & 0.1 & 0.1 & 13302 & 288567 & 16 & 48 \\
\hline Mannheim & 3696 & 110869 & 0.2 & 0.1 & 4115 & 121811 & 90 & 91 \\
\hline Total & 1510147 & 173130315 & 100.0 & 100.0 & 3258936 & 334777547 & 46.3 & 52 \\
\hline
\end{tabular}

Note: ${ }^{\star}$ Indicative share of Central European flights on all flights.

In the air network of the 26 Central European metropolitan cities 269 airlines between 28 airports were registered (the Rhine-Ruhr metro region includes three airports - Düsseldorf, Cologne and Dortmund) in February 2017. These regular airlines include approximately 1.51 million direct flights; the estimated number of passengers based on transport capacity is about 173 million passengers. In total, according to Eurostat data, there were 3.26 million 
flights with a volume of about 335 million passengers in 2015 (see Table 5). It is not surprising that the most important airports are located in Germany: Munich (15\% share of transport performance), Frankfurt (13\%) and Rhine-Ruhr (9\%). Germany's dominant position shows $63 \%$ share of departures and $68 \%$ share of arrivals. The second most important country from this point of view is Switzerland, representing almost $12 \%$ arrivals and more than $13 \%$ departures. The only V4 country with a more significant position than at least one "western" country (Austria) is Poland with adequate shares of $10 \%$ departures and $9 \%$ arrivals, followed by the Austrian position with $6 \%$ departures and $8 \%$ arrivals. The Hungarian and Czech share is about $2 \%$ and Slovakia has less than $1 \%$ share. Figure 3 shows the strongest air links in the Central European region from the perspective of the V4 countries. Individual flights are weighted by the annual capacity of the line, which is measured by the sum of all arrivals and departures. The relevant traffic flow is then assigned to the metropolis whose total arrivals on a given route are greater than the sum of departures (exceptions are where flights are designated by dashed lines despite the greater number of arrivals to the German, Austrian or Swiss metropolises). An important finding is the fact that internal transport of persons within national structures is also essential in air transport. The fact of being located in a more peripheral location that strengthens air transport appears to be a paradoxical advantage for metropolises (e.g. Warsaw). The metropolis located in the central part of the region, such as Prague, is in a less significant position. This finding corresponds to the fact that in the central part of the region it is possible to carry out long-distance transport using other modes of transport, especially road transport (high speed railways due to their absence in V4 countries are not included here).

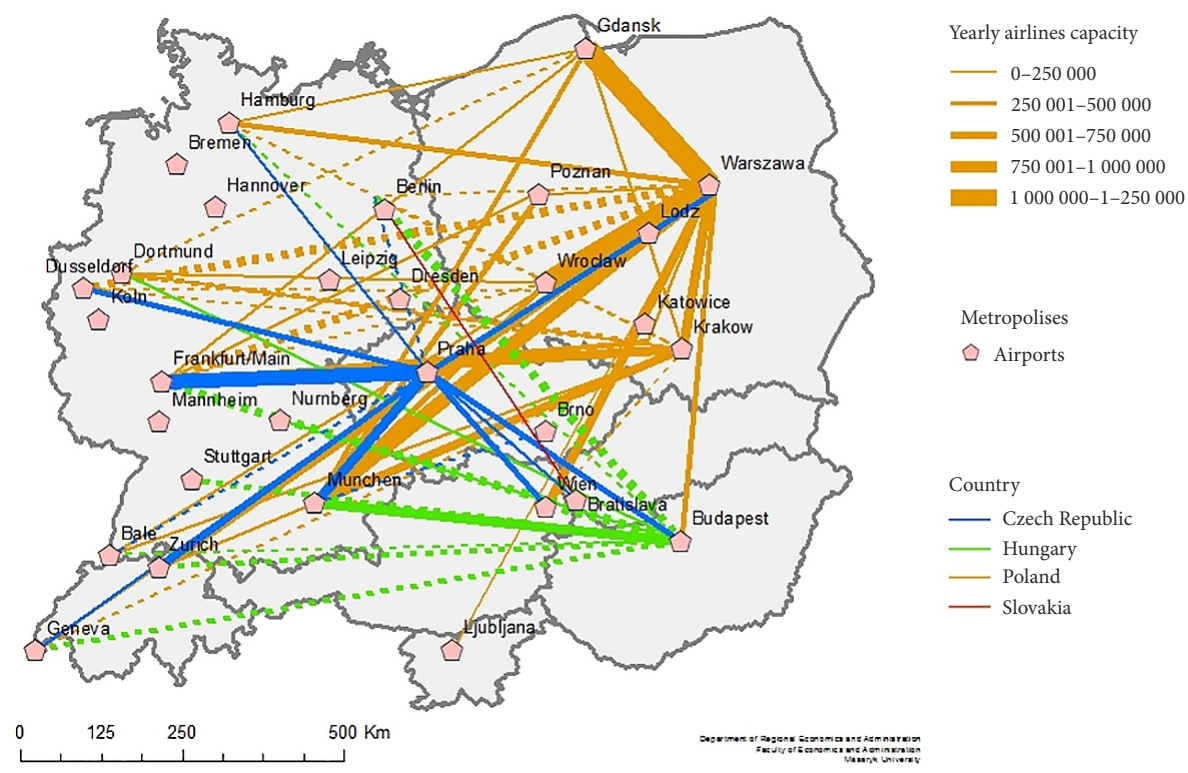

Figure 3. Air transport in the Central European area from the V4 point of view (source: Flightradar24, 2017; own calculations)

Note: Continuous lines represents airlines with arrivals $>$ departures, dashed lines represents airlines with departures $>$ arrivals. 
The overall assessment of aviation connectivity lays in the aggregate annual transmission capacity of the relevant airlines. The follow-up road connectivity assessment (Park \& O'Kelly, 2017) is then performed by determining the average time availability of the V4 metropolises from the contact metropolises located on the axes examined (the map information on the route map www.maps.google.com and www.mapy.cz.). The results of the road and air connectivity evaluation as well as the overall transport connectivity according to the established metropolitan axes are presented in Table 6. The best results are shown on two axes: Budapest - Vienna - Munich and Prague - Nuremberg - Frankfurt am Mein - Ruhr. The second group includes 10 axes with a strong position. The third group includes 6 axes.

Table 6. Transport connectivity (source: Google, 2017; Eurostat, 2017; OECD, 2018; Flightradar24, 2017; own calculations)

\begin{tabular}{|l|c|c|c|c|c|c|}
\hline \multicolumn{1}{|c|}{ Metropolitan Axis } & $\begin{array}{c}\text { Road } \\
\text { (time) }\end{array}$ & R-rank & $\begin{array}{c}\text { Air Cap. } \\
(\%)\end{array}$ & $\begin{array}{c}\text { Air- } \\
\text { rank }\end{array}$ & $\begin{array}{c}\text { Total } \\
\text { points }\end{array}$ & $\begin{array}{c}\text { Total } \\
\text { rank }\end{array}$ \\
\hline Prague - Nuremberk - Munich - Zurich & 4.66 & 2 & 8.38 & 2 & 4 & 2 \\
\hline Prague - Dresden - Berlin - Hamburg & 3.59 & 1 & 2.86 & 3 & 4 & 2 \\
\hline $\begin{array}{l}\text { Prague - Nuremberk - Frankfurt a. M. - } \\
\text { Rhine-Ruhr }\end{array}$ & 4.69 & 2 & 10.66 & 1 & 3 & 1 \\
\hline $\begin{array}{l}\text { Prague - Nuremberk - Stuttgart - } \\
\text { Mannheim }\end{array}$ & 4.16 & 2 & 0.00 & 3 & 5 & 3 \\
\hline $\begin{array}{l}\text { Prague - Dresden - Leipzig - } \\
\text { Hannover - Bremen }\end{array}$ & 3.60 & 1 & 0.00 & 3 & 4 & 2 \\
\hline Prague - Vienna & 3.45 & 1 & 3.70 & 3 & 4 & 2 \\
\hline Prague - Bratislava - Budapest & 3.29 & 1 & 3.46 & 3 & 4 & 2 \\
\hline Prague - Wroclaw - Lodz - Warsaw & 5.39 & 3 & 14.12 & 1 & 4 & 2 \\
\hline Prague - Katowice & 4.27 & 2 & 0.00 & 3 & 5 & 3 \\
\hline $\begin{array}{l}\text { Warsaw - Lodz - Poznan - Berlin - } \\
\text { Hannover - Rhine-Ruhr }\end{array}$ & 4.34 & 2 & 8.45 & 2 & 4 & 2 \\
\hline $\begin{array}{l}\text { Krakow - Katowice - Wroclaw - } \\
\text { Berlin - Hamburg }\end{array}$ & 5.18 & 3 & 1.37 & 3 & 6 & 3 \\
\hline Gdansk - Warsaw - Katowice - Vienna & 5.74 & 3 & 16.71 & 1 & 4 & 2 \\
\hline $\begin{array}{l}\text { Krakow - Katowice - Wroclaw - } \\
\text { Dresden - Leipzig - Rhine-Ruhr }\end{array}$ & 4.32 & 2 & 7.03 & 2 & 4 & 2 \\
\hline Gdansk - Berlin - Rhine-Ruhr & 6.20 & 3 & 1.35 & 3 & 6 & 3 \\
\hline Budapest - Vienna - Munich - Zurich & 4.33 & 2 & 12.08 & 1 & 3 & 1 \\
\hline Budapest - Krakow - Katowice & 5.64 & 3 & 0.00 & 3 & 6 & 3 \\
\hline $\begin{array}{l}\text { Budapest - Nuremberk - } \\
\text { Frankfurt a. M. - Rhine-Ruhr }\end{array}$ & 8.74 & 3 & 9.83 & 2 & 5 & 3 \\
\hline Bratislava - Vienna & 0.83 & 1 & 0.00 & 3 & 4 & 2 \\
\hline Notes: Road time rank & 5 & 2 & 4 & 4 \\
\hline
\end{tabular}

Notes: Road time rank limit for an average group rank 2 are $>4$ and $<5$; air capacity limits for average group are $>5 \%$ and $<10 \%$; the total rank for an average group is 4 points. 
The overall results for air transport show the importance of large national transport markets (the two most important air connectivity axes include Polish metropolises (Prague Wroclaw - Warsaw and Gdansk - Warsaw - Vienna). The comparison of transport connectivity results with TEN-T (European Union [EU], 2013) shows the comparable importance of the two most important East-West metropolitan axes, namely Prague - Rhine-Ruhr and Budapest - Munich, which corresponds with the corridor Rhineland-Danube. In the NorthSouth direction, there is a significant consensus, especially in the Gdansk - Warsaw - Vienna axis which corresponds with the Baltic - Adriatic corridor, whose importance is not only for V4 countries but also for Baltic states (the Prague - Berlin - Hamburg axis, however, appears in the second importance group.

\section{Synthesis and discussion of the positional evaluation}

The final synthesis deals with the positional evaluation of developmental axes of supranational importance of integrating V4 countries within the Central European region. In this context, the following meaningful order of analysed components was respected: general economic interactivity - tourist attractiveness - transport connectivity. Based on the elaborated approach the 15 most important axes were identified (see Table 7).

From the respective axes linking eastern and western parts of the region, six axes refer to the Czech Republic, three axes to Poland and one axis to Hungary and Slovakia; the remaining four axes concern only the eastern part of the region. The results show that the V4 have good prerequisites for economic cooperation with the urban core of Europe, known as the blue banana (Hospers, 2002). From a general point of view, the findings can be understood as a spatial reflection of the functioning of the hierarchical organization of societal systems, which represents a conditio sine qua non of their progressive development. In this respect, the information on supranational systems of development poles and axes that meet the idea of the well-known core-periphery concept is particularly valuable. These territorial links are crucial factors determining the developmental differentiation of societal systems. It can be said that positive development and dynamic balance of all the influencing factors create the prerequisites for the sustainable development of human civilization.

The overall assessment of the most important axes connecting the V4 countries within the Central European region shows that their greatest weakness is transport connectivity. From the persistent discussion of this fact, it is clear that the primary cause is the slow pace of construction of motorways, especially in the Czech Republic and Slovakia (missing motorway links with Austria respectively Poland), while flat Poland and Hungary have made significant progress over the last decade. The rapid development of air transport associated with deregulation of markets has stimulated the growth of tourist activities especially in peripheral metropolises, where it significantly complements road transport. A stronger improvement of transport connectivity can be then expected from the construction of high-speed rails already launched by Poland. 
Table 7. Metropolitan axes - complex final ranking (source: OECD, 2018; Eurostat, 2017; own calculations)

\begin{tabular}{|l|c|c|c|c|}
\hline \multicolumn{1}{|c|}{ Metropolitan Axes } & $\begin{array}{c}\text { Economic } \\
\text { interactivity }\end{array}$ & $\begin{array}{c}\text { Tourist } \\
\text { attractive- } \\
\text { ness }\end{array}$ & $\begin{array}{c}\text { Transport } \\
\text { connectivity }\end{array}$ & $\begin{array}{c}\text { Aggregate } \\
\text { ranking }\end{array}$ \\
\hline Budapest - Vienna - Munich - (Zurich) & 1 & 1 & 1 & 3 \\
\hline $\begin{array}{l}\text { Prague - Nuremberg - Frankfurt a. M. - } \\
\text { Rhine Ruhr }\end{array}$ & 1 & 1 & 1 & 3 \\
\hline Prague - Nuremberg - Munich - Zürich & 1 & 1 & 2 & 4 \\
\hline Prague - Dresden - Berlin - Hamburg & 1 & 1 & 2 & 4 \\
\hline Bratislava - Vienna & 1 & 2 & 2 & 5 \\
\hline $\begin{array}{l}\text { Warsaw - Lodz - Poznan - Berlin - } \\
\text { (Hannover - Rhine Ruhr)* }\end{array}$ & 1 & 2 & 2 & 5 \\
\hline Prague - Bratislava - Budapest & 2 & 1 & 2 & 5 \\
\hline $\begin{array}{l}\text { Krakow - Katowice - Wroclaw - Berlin - } \\
\text { (Hamburg) }\end{array}$ & 1 & 2 & 3 & 6 \\
\hline [Gdansk] - Warsaw - Katowice - Vienna & 1 & 3 & 2 & 6 \\
\hline $\begin{array}{l}\text { Prague - Dresden - Leipzig - Hannover - } \\
\text { Bremen }\end{array}$ & 2 & 2 & 2 & 6 \\
\hline Prague - Vienna & 2 & 2 & 2 & 6 \\
\hline Prague - Nuremberg - Stuttgart - Mannheim & 2 & 2 & 3 & 7 \\
\hline Prague - Wroclaw - Lodz - Warsaw & 2 & 3 & 2 & 7 \\
\hline $\begin{array}{l}\text { Katowice - Wroclaw - Dresden - Leipzig - } \\
\text { (Rhine-Ruhr)* }\end{array}$ & 3 & 2 & 2 & 7 \\
\hline Budapest - Krakow - Katowice & 2 & 3 & 3 & 8 \\
\hline
\end{tabular}

Note: ${ }^{\star}$ Text in brackets “(...)" represents metropolises included in tourist attractiveness and air transport connectivity, text in brackets "[...]" represents metropolises included in transport connectivity.

\section{Conclusions}

The presented evaluation of the Central European metropolises covers the significant determinants of their development with an emphasis on the creation of metropolitan networks, which we consider to be one of the building blocks of territorial integration. The basis of this evaluation was a thorough positional analysis of metropolises using theoretically anchored research methods that were applied to proven data sets. The obtained results can be purposefully used at creation of integrated scenarios of the future development. In this context, we consider the strategic priority to be strengthening and deepening of metropolitan axes of supranational importance. The indisputable dominant role of German metropolises then can be seen as an opportunity to accelerate the development of less developed V4 countries through international trade, production cooperation, transfer of know-how and other (e.g. tourist) interactions. As far as suggestions for long-term research, it is an interesting question to what extent these processes contribute to the fastening of "Central European roots" of relevant countries. Furthermore, in connection with the identified importance of transport 
infrastructure, the next possible way of research is an issue of population mobility behaviour in relation to the development of new high-speed connections between metropolitan areas. In other words, how the technological development of transport systems will transform the analyzed processes and, ultimately, the position of Central European metropolises.

\section{Funding}

This work was supported by the Ministry of Education, Youth and Sports of Czech Republic in the Operational Programme Research, Development and Education [grant "New mobility - high-speed transport systems and transport behaviour of the population" with project number muni 1312/2017, id CZ.02.1.01/0.0/0.0/16_026/0008430].

\section{Authors contribution}

Author 1 contributed to this work with research aimed at the tourism attractiveness of metropolitan areas and axes and their network relations.

Author 2 contributed to this work with research aimed at the economic potential and performance of metropolitan areas and axes focused on identification of key economic metropolitan relationships.

Author 3 contributed to this work with research aimed at the transportation connectivity of metropolitan areas and axes and a focused assessment of dynamic transportation interactions among relevant metropolitan areas.

\section{Disclosure statement}

All three authors declare and confirm they have no any competing financial, professional, or personal interests from other parties related to this paper research.

\section{References}

Arvis, J. F., \& Shepherd, B. (2016). Measuring connectivity in a globally networked industry: the case of air transport. World Economy, 39(3), 369-385. https://doi.org/10.1111/twec.12363

Bieger, T. (2008). Managament von destinationen. München: Oldenburg. https://doi.org/10.1524/9783486711127

Brender, N., \& Golden, A. (2007). Mission impossible: successful Canadian cities. Paper presented at The Conference Board of Canada III. Ottawa, Canada (pp. 222).

Brezzi, M., Piacentini, M., Rosina, K, \& Sanchez-Serra, D. (2012). Redefining urban areas in OECD countries Redefining Urban: a new way to measure Metropolitan areas (pp. 19-58). Paris: Organization for Economic Cooperation and Development. https://doi.org/10.1787/9789264174108-en

Brockhaus Enzyklopädie Jahrbuch 2009. (2010). Leipzig-Mannheim: F.A. Brockhaus.

Calatayud, A., Palacin, R., Mangan, J., Jackson, E., \& Ruiz-Rua, A. (2016). Understanding connectivity to international markets: a systematic review. Transport Reviews, 36(6), 713-736.

https://doi.org/10.1080/01441647.2016.1157836 
Central Intelligence Agency. (2014). The World Factbook. Washington, DC. Retrieved from https://www. cia.gov/library/publications/the-world-factbook/

Cushman \& Wakefield. (2011). European cities monitor. New York: Cushman \& Wakefield.

Duval, D. T. (2013). Critical issues in air transport and tourism. Tourism Geographies, 15(3), 494-510. https://doi.org/10.1080/14616688.2012.675581

Encyclopeedia Britannica. (2011). Britannica Group, Inc., Chicago. Retrieved from https://www.britannica.com/

European Council of Spatial Planners. (2013). The Charter of European Planning. General assembly of ECTP-CEU, Barcelona.

European Union [EU]. (2013). Regulation (EU) No 1315/2013 of The European Parliament and of The Council of 11 december 2013 on Union guidelines for the development of the trans-european transport network and repealing decision no 661/2010/eu. Retrieved from: https://eur-lex.europa.eu/legalcontent/EN/TXT/HTML/?uri=CELEX:32013R1315\&from=CS

Eurostat. (2017). Eurostat air transport statistics. Retrieved from https://ec.europa.eu/eurostat/statisticsexplained/index.php?title=Archive:Air_transport_services_statistics_-_NACE_Rev._2

Flightradar24. (2017). Interactive air transport data provider. Retrieved from https://www.flightradar24. $\mathrm{com} / 48.72,16.39 / 5$

Globalization and World Cities [GaWC]. (2014). Loughborough: Loughborough University, Study Group and Network. Retrieved from http://www.lboro.ac.uk/gawc/

Google. (2017). Google maps planning module. Retrieved from https://maps.google.com

Growe, A. (2012). Emerging polycentric city-regions in Germany. Regionalisation of economic activities in metropolitan regions. Erdkunde, 66(4), 295-311. https://doi.org/10.3112/erdkunde.2012.04.02

Hanssens, H., Derudder, B., \& Witlox, F. (2012). Managing organizational and geographical complexity: the positionality of advanced producer services in the globalizing economies of metropolitan regions. Erdkunde, 66(1), 45-55. https://doi.org/10.3112/erdkunde.2012.01.04

Hospers, G. (2002). Beyond the Blue banana? Structural changes in Europe's geo-economy. In 42nd European Congress of the Regional Science Associaton, Dortmund (pp. 76-85). European Regional Science Association.

Klug, H. (2012). An integrated holistic transdisciplinary landscape planning concept after the Leitbild approach in. Ecological Indicators, 23, 616-626. https://doi.org/10.1016/j.ecolind.2012.05.019

Kraft, S. (2016). Anytime? Anywhere? The seasonality of flight offers in Central Europe. Moravian Geographical Reports, 24(4), 26-37. https://doi.org/10.1515/mgr-2016-0020

Krätke, S. (2006). The metropolization of the European urban and regional system. Globalization and World Cities Research Bulletin, 193.

Krätke, S. (2014). Cities in contemporary capitalism. International Journal of Urban and Regional Research, 38(5), 1660-1667. https://doi.org/10.1111/1468-2427.12165

Liu, X. J., Dai, L., \& Derudder, B. (2017). Spatial Inequality in the Southeast Asian intercity transport network. Geographical Review, 107(2), 317-335. https://doi.org/10.1111/j.1931-0846.2016.12181.x

Mapy.cz. (2017). Czech travel map portal. Retrieved from https://www.mapy.cz

Matsumoto, H., Domae, K., \& O'Connor, K. (2016). Business connectivity, air transport and the urban hierarchy: A case study in East Asia. Journal of Transport Geography, 54, 132-139. https://doi.org/10.1016/j.jtrangeo.2016.05.005

McCann, P. (2010). Urban and regional economics. Oxford: Oxford University Press.

Neumann, U. (2013). City ranking - a useful instrument for regional analysis and policy? Paper presented at the Acatech CAE Workshop A ranking scheme for intelligent cities. Munich, Deutsche akademie der technikwissenschaften. 
Nováček, A. (2012). Dualita Evropy: historickogeografická analýza [Europe’s Duality: Historical Geographic Analysis]. Prague: Česká geografická společnost.

Organization for Economic Cooperation and Development [OECD]. 2012. Redefining "urban": a new way to measure metropolitan areas. Paris.

Organization for Economic Cooperation and Development [OECD]. 2013. Definition of functional urban areas for the OECD metropolitan database. Paris.

Organization for Economic Cooperation and Development [OECD]. 2018. Metropolitan areas. Paris.

Park, Y., \& O'Kelly, M. E. (2017). Exploring accessibility from spatial interaction data: An evaluation of the Essential Air Service (EAS) program in the contiguous US air transport system, Environment and Planning, 49(4), 930-951. https://doi.org/10.1177/0308518X16680816

Parr, J. B. (2014). The regional economy, spatial structure and regional urban systems. Regional Studies, 48(12), 1926-1938. https://doi.org/10.1080/00343404.2013.799759

Potschin, M. B., Klug, H., \& Haines-Young, R. H. (2010). From vision to action: Framing the Leitbild concept in the context of landscape planning. Futures, 42(7), 656-667.

https://doi.org/10.1016/j.futures.2010.04.003

Suau-Sanchez, P.; Voltes-Dorta, A., \& Rodriguez-Deniz, H. (2016). Measuring the potential for selfconnectivity in global air transport markets: Implications for airports and airlines. Journal of Transport Geography, 57, 70-82. https://doi.org/10.1016/j.jtrangeo.2016.09.013

Statistics Poland. (2017). Local Data Bank. Retrieved from https://bdl.stat.gov.pl/BDL/dane/podgrup/ temat

Statistisches Bundesamt. (2016). Vorläufige Ergebnisse. Wiesbaden: Das Statistische Bundesamt. (Date 15 June 2016).

Statistisches Bundesamt. (2017). Regionaldatenbank Deutschland. Retrieved 30 June 2017 from https:// www.regionalstatistik.de/genesis/online

Stimson, J., Stough, R., \& Roberts, B. (2006). Regional economic development. Berlin, Heidelberg, New York: Springer.

TourMIS database. (2017). Marketing-Information-System for tourism managers. Wien: MODUL University Vienna. Retrieved 30 June 2017 from http://www.tourmis.info/

Viturka, M. (2014). Integrative model for evaluation of development potentials of regions and its application on an example of the Czech Republic. Economics and Management, 17(4), 4-19. https://doi.org/10.15240/tul/001/2014-4-001

Viturka, M., Pařil, V., Tonev, P., Šašinka, P., \& Kunc, J. (2017). The Metropolisation Processes - A case of Central Europe and the Czech Republic. Prague Economic Paper, 26(5), 505-522. https://doi.org/10.18267/j.pep.624

Wöber, K. W. (2003). Information supply in tourism management by marketing decision support systems. Tourism Management, 24(3), 241-255. https://doi.org/10.1016/S0261-5177(02)00071-7

Wydział Ekonomiczno-Handlowy - Ambasada RP w Berlinie. (2005). Rynek Niemiecki (Poradnik dla exsporterów i inwestorów). Berlin.

Žítek, V., Klímová, V., \& Králová, M. (2016). Assessment of regional innovation systems as an assumption for innovation policy adjustment. Transylvanian Review of Administrative Sciences, 49, 169-186. 